Portland State University

PDXScholar

7-6-1995

\title{
Indigent v. Non-Indigent Sex Offenders: An Analysis of Sentencing in Clackamas, Multnomah and Washington Counties, Oregon
}

Dorelei Victoria Linder

Portland State University

Follow this and additional works at: https://pdxscholar.library.pdx.edu/open_access_etds

Part of the Criminology and Criminal Justice Commons

Let us know how access to this document benefits you.

\section{Recommended Citation}

Linder, Dorelei Victoria, "Indigent v. Non-Indigent Sex Offenders: An Analysis of Sentencing in Clackamas, Multnomah and Washington Counties, Oregon" (1995). Dissertations and Theses. Paper 5063.

https://doi.org/10.15760/etd.6939

This Thesis is brought to you for free and open access. It has been accepted for inclusion in Dissertations and Theses by an authorized administrator of PDXScholar. Please contact us if we can make this document more accessible: pdxscholar@pdx.edu. 


\section{THESIS APPROVAL}

The abstract and thesis of Dorelei Victoria Linder for the Master of Science in Administration of Justice were presented July 6, 1995, and accepted by the thesis committee and department.

COMMITTEE APPROVALS:

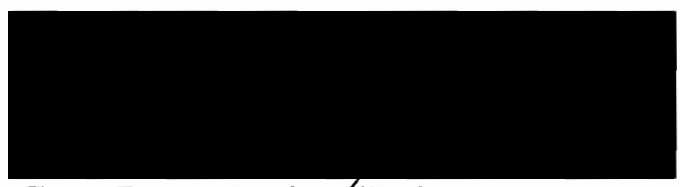

Gary R. Perlstein,/Chair

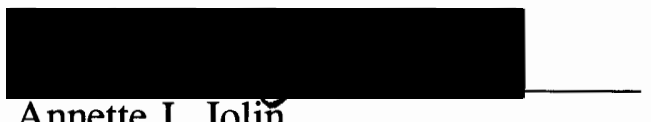

Annette I. Jolin

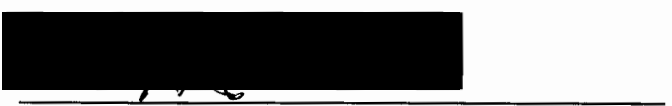

Hugo Maynard

Representative of the Office of Graduate Studies

DEPARTMENTAL APPROVAL:

Robert $\bar{W}$. Lockwood, Chair

Department of Administration of Justice

$* * * * * * * * * * * * * * * * * * * * * * * * * * * * * * * * * * * * * * * * * * * * * * * * * * * * * * * * * * * * * * * * * * * * * * * *$

ACCEPTED FOR PORTLAND STATE UNIVERSITY BY THE LIBRARY

by

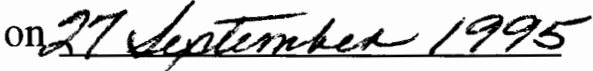




\begin{abstract}
An abstract for the thesis of Dorelei Victoria Linder for the Master of Science in Administration of Justice presented July 6, 1995.

Title: Indigent v. Non-Indigent Sex Offenders: An Analysis of Sentencing in Clackamas, Multnomah and Washington Counties, Oregon
\end{abstract}

The present paper is a descriptive study of sex offender sentencing in three Oregon counties in 1992. It examines the relationship between sentencing practices and indigent offenders. It focuses specifically on the question of offender indigent status and court ordered sex offender treatment. The study also provides information about the number of sex offenders in each of the three counties, how the offenders' sentences were determined by the courts through the use of the sentencing guidelines matrix, what type of plea was used, and what if any influence indigence had in the sentencing outcomes for the felony sex offenders in this study.

Viewed from a conflict theoretical perspective, it was expected that indigent sex offenders would experience differential treatment by the courts. Two-tailed chi-square tests were computed to determine if a difference exists between sentences given indigent and non-indigent offenders. The same tests were applied to determine if there exists a difference between indigent and non-indigent in regard to the addressing of treatment in the sentence order.

The tests were considered significant at the .05 level. A significant difference was found between probation sentences and prison sentences for indigent versus non- 
indigent offenders.

Frequency scores were examined for this study by the number of indigent sex offenders that were convicted in each sample county for 1992, guilt type, guilt type and sentence, sentencing guidelines matrix score, indigence and race, and treatment by county.

There is minimal information on the topic of sex offenders and the possible relationship between indigence, sentence disposition and treatment. The information contained in this study will contribute to the body of knowledge in the area of sex offenders and the results of this study will provide information useful for further research. 
INDIGENT V. NON-INDIGENT SEX OFFENDERS:

AN ANALYSIS OF SENTENCING IN CLACKAMAS, MULTNOMAH AND WASHINGTON COUNTIES, OREGON

by

DORELEI VICTORIA LINDER

A thesis submitted in partial fulfillment of the requirements for the degree of

\author{
MASTER OF SCIENCE \\ in \\ ADMINISTRATION OF JUSTICE
}

Portland State University

1995 


\section{TABLE OF CONTENTS}

ACKNOWLEDGMENTS .................... iv

LIST OF TABLES $\ldots \ldots \ldots \ldots \ldots \ldots \ldots \ldots \ldots \ldots$

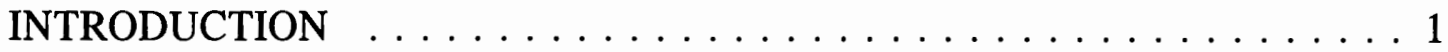

The Issue of Treatment $\ldots \ldots \ldots \ldots \ldots \ldots$

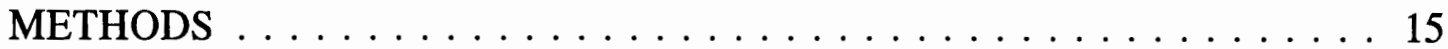

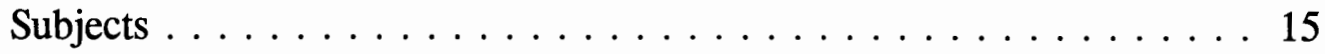

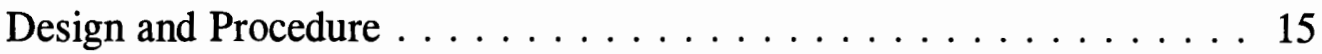

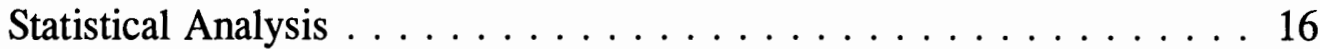

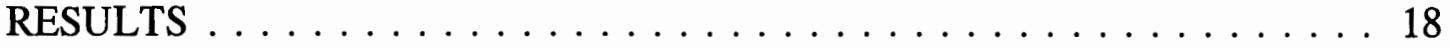

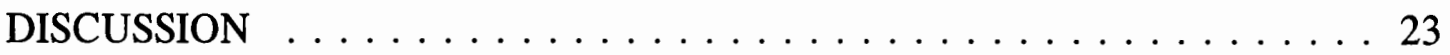

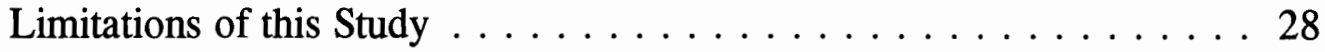

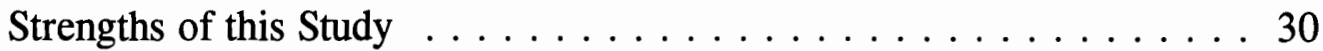

DEFINITIONS AND TERMS $\ldots \ldots \ldots \ldots \ldots \ldots \ldots \ldots \ldots \ldots$

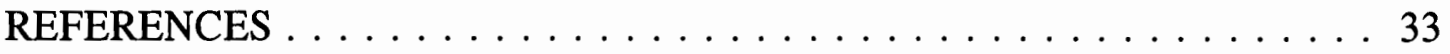

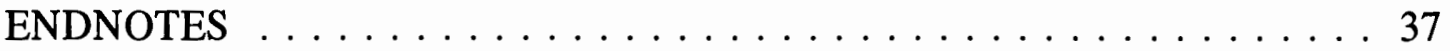

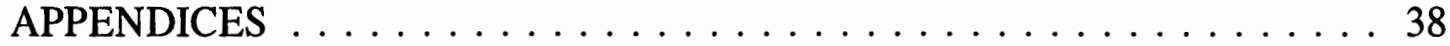

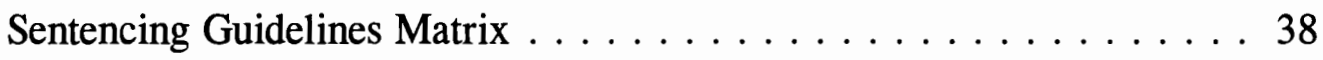

Felony Sentencing Report . . . . . . . . . . . . . . . . . . 39 


\section{ACKNOWLEDGMENTS}

I would like to thank the Oregon Criminal Justice Council for providing the data and reports used in this study. Thanks also goes to the professionals of the community corrections departments in Clackamas, Multnomah and Washington counties who provided answers and materials for all questions that arose, and thanks to the professionals in the field of sex offender treatment for their candor.

This chapter in my life could not have been completed without the unending guidance and support of Gary Perlstein, Ph.D., Annette Jolin, Ph.D., Hugo Maynard, Ph.D., David Blanchard, Ph.D., and Michael Costello for his daily encouragement. Thanks also to Richard Bash who was there for me at "crunch time."

As this work has taken me away from more pleasurable pursuits, I thank Thomas for his understanding the need for long hours behind the computer and long hours away from home. This is for my mother, and Jerry Blake, Professor Emeritus; they both taught me to look beyond what I see on the surface of people who have problems.

Lastly, I dedicate this thesis to my son Neil, whose love made it all worthwhile. 


\section{LIST OF TABLES}

TABLE

PAGE

1 Imprisonment Rates by Conviction Offenses: 1986 and 1991-1992 8

2 Chi-square results between indigence and sentence 19

3 Chi-square results between indigence and prison treatment 20

$4 \quad$ Chi-square results between indigence and probation treatment 21

$5 \quad$ Chi-square results between indigence and treatment 22 


\section{CHAPTER I}

\section{INTRODUCTION}

The history of governmental involvement with those characterized by poverty, specifically from the first Poor Laws in England, marked the beginning of government social welfare legislation and policies in the United States (Piven and Cloward, 1971 and Woodroofe, 1966).

Poor laws, developed in the early seventeenth century, required that the poor, vagrants, and vagabonds be put to work in public or private enterprise. Houses of corrections were developed to make it convenient for petty law violators to be assigned to work details and be put to work in public or private enterprise. (Senna and Seigal, 1984)

The need for these houses of corrections came from the great increases in the number of poor. England moved out of feudalism and isolated fiefdoms into the cultivation of urban centers, which left many detached and impoverished. These individuals became the petty law violators, violating as a means of survival. The growth of this class of poor gave the English rulers new social problems to which they responded with increasing punitive measures (Irwin, 1985).

The perceptions that the poor are the cause of crime can be found throughout the writings on the poor and the criminal justice system. Goffman (1963) wrote about the stigma of poverty, and Matza's (1962) concept of the disreputable poor took into account the judgements made by other members of society. Many judgements made of the poor regarding crime (i.e., they steal, mug, are loose sexually) are judgements made by the non-poor in an attempt to explain away the situational concerns of the 
poor.

Donald Cressey (1961) questioned the reliability of crime statistics that showed an over-representation of lower class persons, therefore, creating the illusion that there really is a class difference in criminality. John Irwin (1985) found that beyond the shared characteristics of poverty, those incarcerated also share two essential characteristics: detachment and disrepute. He writes, "They are detached because they are not well integrated into conventional society . . . they are carriers of unconventional values and beliefs. They are disreputable because that are perceived as . . offensive, threatening, capable of arousal."

According to Sutherland (1949), most official records ignore the area of crime where the perpetrators are able to escape arrest and prosecution, or when prosecuted, afford the less punitive way out.

Founded in 1961, the Vera Institute of Justice began researching areas in the administration of criminal justice based upon penalization of certain individuals because of their economic status. Established as a research organization with the objective of achieving a more equal and fair criminal justice system, the Vera Institute's study regarding sentencing in the Bronx court system (Manhattan Bail Project, 1967) found that crimes committed by the poor result in tougher sentences than those committed by the non-poor. The Institute's exploration into sentencing reform worked to address the type of reform necessary toward equality for all regardless of economic status.

Other attempts at reform by the Vera Institute include releasing defendants on 
personal recognizance. For this process, the suspects are carefully screened and selected according to such criteria as length of residence, employment record, and ties with relatives. Sykes (1978) points out that despite the encouraging results at this type of reform, the system of bail continues as a blatant example of economic discrimination and persists in imprisoning suspected offenders without trial.

Chiricos, Jackson and Waldo (1972) found that when individuals are accused of similar offenses with similar prior records, the poor defendants more likely to be adjudicated guilty than the wealthier defendants. Myer (1987) examined the issue of income inequality and sentencing, finding support that there is differential treatment based upon an offenders attributes and behavior.

Conflict theory suggests that society is made up of multiple, overlapping groups with differing interests, values and norms. The literature suggests that the criminal justice system treats indigent offenders differently than it does non-indigent offenders. Sentencing practices are part of the criminal justice system process, hence, one would expect differences in sentences for indigent and non-indigent offenders.

The working hypothesis of this paper asserts that indigent status influences sex offender sentencing. Indigent offenders are more likely to be sentenced to prison than non-indigent offenders and indigent offenders are less likely to receive court-ordered sex offender treatment that non-indigent offenders.

According to Vold (1958), the fundamental assumption of conflict theory is that societies are more appropriately characterized by conflict rather that by consensus. Due to this, conflict brought about through deviance, by some, from the acceptable 
parameters of social behavior is positive, in that it forces the conflicting parties to accept that what may be "normal" for one, is not "normal" for the another.

For this particular study the focus is on sex offender sentencing and the possible influence that the socio-economic status of a sexual offender has on the sentence disposition that is given and whether or not the type of sentence received addresses treatment.

According to the Sixth Amendment, in the administration of criminal law, the indigent has the right to have the assistance of counsel when accused of violation of the law. The United States Supreme Court decision in Betts v. Brady (1942) ruled that the indigent criminal defendant in federal court has the right to free counsel; this was extended in Gideon v. Wainwright (1963). It was ruled that individuals who cannot afford counsel have the right to have counsel appointed for them in state courts for non-capital criminal cases. In 1965 Michael Moore examined the issue of right to counsel for indigence in Oregon. In his research he found that $55 \%$ of the defendants were deemed indigent (Moore, 1965). The State of Oregon has historically guaranteed the right to counsel to all, as found in the state's Constitution. ${ }^{1}$

For those accused of criminal law violations, there are two general options for legal representation. The first is retention of private counsel for those defendants who have the money, and the other, indigent defense attorneys for those defendants who do not have money.

According to Sudnow (1965) the general belief about indigent defense representation is that it is less adequate than the representation provided by an 
attorney the defendant has personally chosen. This paradox stems from a very real concern that defendants have regarding the degree of advocacy the state funded attorney will provide them in a case where the adversary is the state. This point is illustrated by Casper (1978), regarding the defendant's perspective on the use of public defenders.

Blumberg (1967) discovered that although it has been recognized that many indigent defense attorneys begin their jobs with a commitment to defending their clients' rights, there is the disillusionment from the discovery that the system is not set up to allow court-appointed attorneys the time or the resources necessary to engage in vigorous, spirited and expensive defense work. Regarding the issue of counsel, Blumberg (1971) found that since high quality legal costs are high, and the ability to devote adequate time and energy to case is minimal for any client, it is more so for the poor.

In determining an appropriate sentence in a particular case, judges have traditionally regarded the harm caused by the offense, the offender's culpability and rehabilitation prospects, and whether justice required the exercise of mercy. This is discretionary individualized justice. (Burke, 1995)

In the past two decades, particularly in the United States, there has been a flurry of discussion and writing on the judiciary's use of its discretionary power in the sentencing process. There has been particular concern over the courts' powers to determine whether a particular offender should be imprisoned, the length of the term of imprisonment, and that the courts' dispersion of penalties is inconsistent, in that, 
like cases are not treated alike. Where these disparities occur, the administration of justice is seen as unfair and generates within the community, a lack of confidence in the courts.

In November 1989, the Oregon Legislature, in an attempt to provide equity adopted into law the Felony Sentencing Guidelines. These guidelines focused on particular sentencing issues of concern to the State of Oregon.

Those issues were stated in the objectives of the guidelines:

- to achieve determinant sentencing

- to reduce disparity in sentencing

- to stay within correctional resources

- to ensure like offenders receive like sentences

Oregon's sentencing guidelines set presumptive sentences for convicted felons based on the seriousness of the crime of conviction and the offender's criminal history. The instrument developed for this purpose is the Sentencing Guidelines Matrix. The seriousness of the crime is determined in levels that range from one to eleven, with murder ranked highest at crime seriousness category 11. (See Appendix A).

An offender's criminal history is based on the number and severity of prior felony and adult Class-A misdemeanor convictions.

The guidelines distinguish between adult and juvenile convictions, felony and misdemeanor convictions and between person and non-person convictions. Ranging from "A" for an offender with 3 or more prior convictions for person-to-person 
crimes, to "I" for an offender with no prior felony or adult class-A misdemeanor convictions, the offender's criminal history falls in one of the nine categories. The guideline grid has the crime seriousness on the vertical axis and the criminal history scale on the horizontal axis. The solid black line represents the dispositional policy, or in other words, the sentence that falls around this line can go either way, prison or probation, depending on mitigating or aggravating circumstances. Sentencing guidelines attempt to limit sentencing disparity by structuring the use of judicial discretion. The sentence disposition submitted by the courts via Felony Guidelines Sentencing Report form (Appendix B), is recorded by the Oregon Criminal Justice Council (OCJC) and used to create the guidelines monitoring database, the very database used for this research. Judges may depart from the presumptive guideline's sentence and impose a sentence more severe or less severe. The judge is required to state on the record the "substantial and compelling" reasons for the departure.

In regard to the sentencing of sex offenders, according to Ashford and Mosbaek (1992), departures occurred most frequently for crimes that included Sex Abuse I; these were all upward durational departures with a median deviation upwardly of 19 months. According to the OCJC's, Third Year Report on Implementation of Sentencing Guidelines, 1992, (Mosbaek, 1993), in the State of Oregon the most increased imprisonment rate since the guidelines have been in effect, has been for sex crimes; for example, the imprisonment rate for Sex Abuse I has more than tripled, from $11 \%$ under the pre-guidelines system to $40 \%$ under guidelines. The average length of prison stay for those convicted of forcible sex crimes has almost doubled 
since the guidelines went into effect.

\section{TABLE 1}

Imprisonment Rate by Conviction Offense: 1986 and 1991-92 (Martin and Hutzler, 1993)

\begin{tabular}{|l|l|l|}
\hline CONVICTION OFFENSE & 1986 & $1991-92$ \\
\hline All Offenses & $18 \%$ & $18 \%$ \\
\hline Sex Offenses & $26 \%$ & $51 \%$ \\
\hline Other Person Offenses & $34 \%$ & $42 \%$ \\
\hline Rape I, Sodomy I, & $59 \%$ & $82 \%$ \\
Penetration I & & \\
\hline Other Rape, Sodomy, & $22 \%$ & $25 \%$ \\
Penetration & & \\
\hline Sex Abuse & $11 \%$ & $40 \%$ \\
\hline
\end{tabular}

Martin and Hutzler (1993) examined imprisonment rates for sex offenders and found an increase under sentencing guidelines. The increase in imprisonment rates after guidelines implementation was most dramatic for sex abuse offenders, but rape and sodomy offenders are also now much more likely to receive sentences to prison.

A stated goal of the guidelines is to treat like offenders similarly. One of the major impacts of sentencing guidelines has been the frequency with which presentence investigators recommend prison instead of a probation disposition, most notably for sex offenders. In the past, almost all but the most violent sexual offenders were recommended for probation. According to the OCJC (1992), the State of Oregon, Department of Corrections pre-sentencing guidelines philosophy was that it would 
give clients, including sex offenders, that were of marginal risk to the community, the opportunity to participate in treatment, and if they failed to make progress, probation could be revoked and they could be sent to prison at that point. The department now follows the guidelines and recommends prison or probation according to the presumptive sentence, unless there are bona fide aggravating or mitigating circumstances. As a result, many incest offenders convicted of A or B felonies are sent immediately to prison.

There exists a paradox in the criminal justice system between what is beneficial in attempting to keep offenders from recidivating and what actually aggravates the potential for recidivism. A paradox is created, in that, society demands swift and deliberate punishment for sex offenders, yet the cost of such a reactive approach does nothing to address the reasons why the offense was committed.

MacLeod (1965) found that society questioned why the prison system, with is stated objective to reform and rehabilitate, turn three out of four first-time offenders into recidivists. According to Petersilia and Turner (1987), very little thought has been given to the latent effects of total mental and physical incapacitation prisons provide. Petersilia and Turner (1986) found there are basic differences between probationers and prisoners. It is generally considered that prisoners are more serious criminals, a generalization cited by this author with reservation, and the prison experience endows characteristics to the offender which are associated with recidivism. These characteristics commonly contribute to prisoners having higher recidivism rates. 
Joan Petersilia and Susan Turner (1986) measured the association between prison or probation and recidivism. The majority of prisoners and probationers recidivated during the two years following their release into the community. However, the findings pointed to imprisonment being associated with a higher probability of recidivism. The prisoners had higher recidivism rates than the probationers, with $72 \%$ of the prisoners rearrested, as compared with $63 \%$ of the probationers; $53 \%$ of the prisoners had new charges filed, compared with $38 \%$ of the probationers; and $47 \%$ of the prisoners were incarcerated in jail or prison, compared with $31 \%$ of the probationers. According to the authors, these data could be interpreted in several ways; the prison experience itself made the offenders more likely to recidivate; society and the criminal justice system's response to the offender may have aggravated the likelihood of recidivism; being an ex-prisoner reduces employment possibilities more than being an ex-probationer, thus the prison label along with the experience compounds the probability.

Wright (1991) found that of all the sanctions that least contribute to the reduction of criminal behavior, prison looms the largest. The deprivation of liberty as a sanction against further criminal behavior is rarely successful with the majority of those who have been through it.

The "lock-em-up-and-throw-away-the-key" mentality in the punishment of offenders is actually punishing the taxpayers more than the criminals. Colson (1991) cites, that according to 1991 FBI statistics, $74 \%$ of released prisoners are re-arrested within four years and a recent Bureau of Prisons study found that the re-arrest rate is 
lowest among those who have spent the least time in prison.

Though sexually offensive behavior has been prevalent in American society for generations, criminal justice research in this specialized area is relatively new, as it has only been during the last two decades that there has been a dramatic increase in the number of sex offenders who have come to the attention of the courts, correctional agencies, social service organizations and mental health professionals.

\section{The Issue of Treatment}

One of the main goals in sentencing sex offenders is to protect the community from further sexual aggression. It is essential that professionals in the field of criminal justice discriminate between those offenders who must be incarcerated to protect the public and those offenders who can be supervised with reasonable safety in community settings. Ideally every sex offender should receive treatment. In treatment, the offender is encouraged to articulate fears, anxieties, wishes, fantasies, and ambitions to relieve mental and emotional distress.

A recent 1991 survey of correctional administrators revealed that there were approximately 85,650 sexual offenders in federal and state prisons. All 48 states participating in this survey, as well as the Federal Bureau of Prisons and the District of Columbia, reported that they provided individual andlor group counseling for these offenders. $^{2}$

The attainment of the goal to reduce the chance of recidivism, is attempted in concert with allowable sanction options, such as probation with or without the ordered 
condition of sex offender treatment or prison with or without the recommendation of participation in sex offender treatment. Maletsky (1991) has found that this population of offender is multi-faceted and many theories have been examined in an attempt to address possible treatment modalities. One theory generated from the mental health field, looks toward treating the symptoms of the sex offender's deviant behavior in an attempt to determine the cause of such behavior.

This approach has proven successful with some sexual offenders. It is important to remember that there are varying degrees of sexual offenses, as there are different types of treatment programs which attempt to address the varying symptoms and causes of sexually deviant behavior. One form of the treatment approach, behavior modification, theorizes that certain socializing skills are absent from the background of the sexual offender. It is important to remember that just as there are varying types of sexually offenses behavior, there are varying types of treatment to address those specific behaviors. In order for treatment to be effective, the right type of treatment must be matched with the specific type of behavior to be modified. In other words, deprivation of liberty would exacerbate the problem, where as treatment has the potential to address the problem.

Behavior modification therapy, employed on a one-to-one basis, addresses sex education, human sexuality, coping mechanisms, relapse prevention, stress and anger management, social skills and substance abuse. Completion of behavior modification therapy is associated with changes in the following areas:

a. An increase in personal responsibility and decrease in the use of justifications for sexual crimes. 
b. Less depression and social introversion.

c. Improved self-esteem.

d. A decrease in deviant sexual arousal.

e. Self reports on learned preventative skills that

will help participants to avoid re-offending

For 1992 in Clackamas, Multnomah and Washington counties, there were sex offender treatment services available for the indigent if the offender received a probationary sentence with the ordered condition of treatment. The programs are expensive and limited to about 10 participants for each 12-24 month session.

Treatment can be ordered by the court if the sentence is probation but can only be recommended if the sentence is prison, the logic being that prison is the harshest punitive measure, therefore, no other conditions of can be ordered. The program available for those offenders sentenced to prison is provided by specialists who contract with the state to perform treatment services during the incarceration period, but only if the offender is amenable, this treatment cannot be ordered, only recommended by the court.

Gigeroff (1980), discovered that the task of sentencing sex offenders is a difficult one for judges. Most judges recognize that those who commit these types of offenses need what the criminal justice system most often cannot give them; an approach which allows for a broader focus than just crime and punishment; a focus which includes treatment.

The approach currently taken by most courts is one of disposal of these cases in an expedient manner so as not to have to dwell on the revulsion and offensiveness of the circumstances. There is a perception that most judges must impose sentences of 
punishment with a sense of frustration because there is an absence of a rational and proper alternative. Most lawyers avoid dealing with sex offense cases because of the sense of contamination of the subject-matter. In some sex offender cases, the judge must often deal with not only the public's "voyeuristic element" but also the antagonistic pressures of the press which adds to the community's sense of outrage and the offender's condemnation.

Gigeroff (1980) makes the point that there is a lack of treatment alternatives for these offenders, and that the "treatment" most sex offenders receive in prison is not from trained psychiatrists, psychologists and social workers, but from other offenders in the form of beatings and rape.

One tool used by criminal justice professionals in an attempt to keep sexual offenders from repetitive criminal behavior is treatment. This study will observe the disposition of sentences given to sex offenders with court appointed attorneys versus sex offenders with privately retained counsel and whether the issue of sex offender treatment was addressed in the sentence disposition. This thesis will examine the sentencing dispositions for convicted sex offenders, with a particular focus on the status of the offender, (i.e., indigent versus non-indigent) and will attempt to answer three questions:

1. How many indigent sexual offenders were sentenced in these counties in 1992 ?

2. What were the sentences of these offenders?

3. Was treatment addressed in the sentences of these convicted sex offenders. 


\section{CHAPTER II}

\section{METHODS}

\section{Subjects}

Subjects of this research were the total population of 251 sex offenders sentenced from Clackamas $(n=36)$, Multnomah $(n=169)$, and Washington counties $(n=46)$, during 1992.

\section{Design and Procedure}

Data was collected from the 1992 Felony Sentencing Report data base maintained by the Oregon Criminal Justice Council (OCJC). Additional information was obtained through the Oregon Justice Information Network (OJIN), maintained by the Oregon Department of Justice.

OJIN provided information as to whether defense counsel was court appointed or privately retained. This information was used to establish indigence. Defendants with court-appointed counsel were considered indigent.

Variables were defined and coded as follows:

Status:

Indigent (indigent defense) (0)

Non-indigent (private counsel) (1)

County:

Clackamas County (3)

Multnomah County (26)

Washington County (34) 
Sentence disposition for immediate crime(s) in 1992:

Probation (Prob) (0)

Prison (Pris) (1)

Treatment:

Sentenced to prison with treatment (prit-1)

Sentenced to prison without treatment (prit-0)

Sentenced to probation with treatment (prot-1)

Sentenced to probation without treatment (prot-0)

Treet: ${ }^{3}$

Pooled sentences of prison and probation, with or without treatment

$\underline{\text { Statistical Analysis }}$

The main purpose of this study is to examine if a relationship exists between indigent status, the type of sentence and treatment a sex offender receives.

Chosen to test the following hypotheses was a chi-square analysis at a significance level of .05 , two-tailed.

Hypothesis one $\left(\mathrm{H}_{1}\right)$ :

The sex offender's sentence is independent of indigence.

Hypothesis two $\left(\mathrm{H}_{2}\right)$ :

Treatment is independent of indigence.

This study also reports descriptive statistics for the following variables: 
- count of how many sex offenders were sentenced by county

- type of plea bargain (guilt) most frequently used

- count of guilt types and sentence

- count of the most present matrix score of the population

- count for indigence by race

- count for treatment by county 


\section{CHAPTER III}

\section{RESULTS}

\section{Descriptive Statistics}

Frequencies revealed that Clackamas County had a total of 36 sex offenders convicted in 1992 , and of those, $80 \%$ were indigent; Multnomah County had a total of 169 sex offenders with $92 \%$ indigent; Washington County had a total of 46 sex offenders with $67 \%$ indigent.

The most used plea bargaining guilt type for indigent offenders across all counties, was "plea with charges dropped" at 123 of 215 . This guilt type was used in $58 \%$ of 36 cases in Clackamas County, $53 \%$ of 169 cases in Multnomah County, and $67 \%$ of 46 cases in Washington County; 62 of 113 probation sentences used the guilt type "plea with charges dropped," while 79 prison sentences of 138 used the same guilt type, across all counties.

The sentencing guidelines matrix score 8 -I was used in $53 \%$ of the 36 cases in Clackamas County, $37 \%$ of the 169 cases in Multnomah County, and $41 \%$ of the 46 cases in Washington County.

A sentence of prison was found in $56 \%$ of the 36 cases in Clackamas County, $57 \%$ of 169 cases in Multnomah County, and $46 \%$ of 46 cases in Washington County.

Treatment by county revealed that Clackamas did not have treatment addressed in the sentencing order in $25 \%$ of 36 cases, Multnomah did not in $60 \%$ of 169 cases, and Washington did not in $63 \%$ of 46 cases.

Indigence by race revealed that of 172 white sex offenders, 141 were indigent and 
31 were non-indigent; for 15 Hispanic sex offenders, 14 were indigent and one was non-indigent; for 51 black sex offenders, 48 were indigent and 3 non-indigent; for 4 native America sex offenders, all were indigent; for 4 Asian sex offenders, 3 were indigent, 1 non-indigent, and of 5 "other," all were indigent.

\section{Relationship between Status and Sentence}

Hypothesis one, that sentence was independent of indigence, was supported. Cross tabulation of indigence by sentence revealed 90 indigent offenders received probation and 125 received prison sentences for their crimes. For non-indigent offenders, 23 received probation and 13 received prison sentences. Chi-square was found to be significant at the .05 level; $\mathrm{X}^{2}(1, \mathrm{~N}=251)=6.045 \underline{\mathrm{P}}<.05$.

\section{TABLE 2}

Frequencies: Indigent by Sentence

\begin{tabular}{|l|l|l|l|}
\hline & PROBATION & PRISON & TOTAL \\
\hline INDIGENT & 90 & 125 & 215 \\
\hline NON-INDIGENT & 23 & 13 & 36 \\
\hline TOTAL & 113 & 138 & 251 \\
\hline
\end{tabular}

Test Statistic Pearson Chi-Square Value: 6.045 DF: 1 Prob: 0.014 
Relationship between Status and Treatment

Hypothesis two was not supported. Cross tabulation of indigence by prison treatment (using only the part of the population that received prison as a sentence), showed 89 indigent offenders did not have the recommendation of treatment addressed in their order, while $36 \mathrm{did}$. For non-indigent offenders, 11 did not have the recommendation of treatment addressed in their order, while 2 did. There was not a statistically significant difference between indigents and non-indigents with respect to prison treatment. This finding does not support the hypothesis that the economic status of a sex offender influences whether treatment is addressed in conjunction with a sentence of prison.

\section{TABLE 3}

Frequencies: Indigent by Treatment Addressed in Prison Sentence

\begin{tabular}{|l|l|l|l|}
\hline & $\begin{array}{l}\text { TO PRISON W/O } \\
\text { TREATMENT }\end{array}$ & $\begin{array}{l}\text { TO PRISON WITH } \\
\text { TREATMENT }\end{array}$ & TOTAL \\
\hline INDIGENT & 89 & 36 & 125 \\
\hline NON-INDIGENT & 11 & 2 & 13 \\
\hline TOTAL & 100 & 38 & 138 \\
\hline
\end{tabular}

Test Statistic Pearson Chi-Square Value: 1.062 DF: 1 Prob: 0.303 
Hypothesis two was not supported. Cross tabulation for indigence by probation treatment (using only the part of the population that received probation as a sentence), showed 35 indigent offenders did not have the recommendation of treatment addressed in their order, while 55 did. For non-indigent offenders, 7 did not have the recommendation of treatment addressed in their order, while 16 did. There was not a statistically significant difference between indigents and non-indigents with respect to probation treatment.

This finding does not support the hypothesis that the economic status of a sex offender influences whether treatment is addressed in a sentence of probation.

\section{TABLE 4}

Frequencies: Indigent by Treatment Addressed in Probation Sentence

\begin{tabular}{|l|l|l|l|}
\hline & $\begin{array}{l}\text { TO PROBATION } \\
\text { W/0 TREATMENT }\end{array}$ & $\begin{array}{l}\text { TO PROBATION } \\
\text { WITH } \\
\text { TREATMENT }\end{array}$ & TOTAL \\
\hline INDIGENT & 35 & 55 & 90 \\
\hline NON-INDIGENT & 7 & 16 & 23 \\
\hline TOTAL & 42 & 71 & 113 \\
\hline
\end{tabular}

Test Statistic Pearson Chi-Square Value: 0.561 DF: 1 Prob: 0.454 
An additional test was performed to determine if there was a relationship between treatment and indigence. In the final test, both prison and probation sentences with treatment addressed or not, were pooled together against indigent or non-indigent. Hypothesis two, again, was not supported. Cross tabulation for indigence by treatment showed 124 indigent offenders did not have the recommendation of treatment addressed in their order, while 91 did. For non-indigent offenders, 18 did not have the recommendation of treatment addressed in their order, while 18 did. There was not a statistically significant difference between indigents and non-indigents with respect to treatment.

This finding does not support the hypothesis that the economic status of a sex offender influences whether treatment is addressed in a sentence.

\section{TABLE 5}

Frequencies: Pooled Prison/Probation Sentence with/without Treatment Addressed

\begin{tabular}{|l|l|l|l|}
\hline & $\begin{array}{l}\text { TO PRIS/PROB } \\
\text { W/0 TREATMENT }\end{array}$ & $\begin{array}{l}\text { TO PRIS/PROB } \\
\text { WITH } \\
\text { TREATMENT }\end{array}$ & TOTAL \\
\hline INDIGENT & 124 & 91 & 215 \\
\hline NON-INDIGENT & 18 & 18 & 36 \\
\hline TOTAL & 142 & 109 & 251 \\
\hline
\end{tabular}

Test Statistic Pearson Chi-Square Value: 0.739 DF: 1 Prob: 0.039 


\section{CHAPTER IV}

\section{DISCUSSION}

Sellin (1958) and Sutherland (1947) suggests that conflict emerges as those in dominant socio-economic positions keep control over those lesser through legal and enforcement means, and how this method of dominance lends to the distribution of the "criminal" label and consequent perpetuation of criminality.

The finding for sentence being independent of status would support the hypothesis that class conflict exists in the relationship between indigence and sentence. It seems to support the working hypothesis that the economic status of a sex offender influences the type of sentence received.

According to Merton (1949), deviant behavior represents efforts to reach culturally prescribed goals through culturally tabooed means, and this process is quite real to the deviant. If the deviant were to find legitimate means to attain the same goal, it would be less likely that deviant behavior would be engaged in.

Conflict and criminality has been examined by Turk, (1966), through four conceptual relations; the first, is criminal behavior as an indicator of conflict within the person. Second, criminal behavior as an expression by the offender. This manifests as an attempt to solve adjustment problems through mimicking the norms of a criminal subculture.

Third, the occurrence of criminal behavior due to having been socialized in a culture that either does not know or does not accept certain legal norms. (Note: Turk defines legal norms as a cultural norms officially announced in a collective.) 
And fourth, the actual violation of legal norms by individuals in a criminal subculture, that manifest the belief that there exists a conflict between what the criminal subculture believes and what are the established legal norms, in an effort to gain authority.

Turk (1976) discovered that in conflicts within a close group, the more intensely one side hates the other, the more it is felt to be a threat to the unity and the identity of the group. Turk's discussion of law as power and how that power is employed in an attempt to resolve conflict, actually exacerbates conflict by its use in an exploitive and disruptive manner.

Regarding criminal stigmatization, Turk goes on to point out, that a person is not judged by what he is or what he does, but rather, he is judged by others perceptions of his behavior, and whether that behavior is offensive or unoffensive, dependent upon who is doing the judging. Examples given, are the experiences of ex-convicts and persons who have been accused but found legally innocent of certain types of offenses, such as arrest on a charge of violation of a sex offender statute; even thought the case may subsequently have been dismissed, this is considered by employers sufficient enough to disqualify an individual for certain types of employment. Therefore, it is the consequences of behavior, not necessarily the behavior itself, that determines the level of conflict.

Quinney (1977) supports the position that justice as a concept is materially based. The concept of justice has evolved with the development of capitalism.

Nadar (1990) describes that justice cannot be thought of as always just and fair, 
but more realistically, as pervasive, powerful and sometimes effective. Nadar describes that it is society's obsessive need for justice that drives the hunt for injustice. In doing so, there is further division between classes, by punishing those who do fit the dominant class values and morals.

This study has examined the sentences given to indigent versus non-indigent sex offenders in Clackamas, Multnomah and Washington counties in 1992. It has further examined whether treatment was addressed in those sentences, how many sex offenders moved through these counties, what type of guilt was plead to, where these sex offenders scored on the sentencing guidelines matrix, and how the sample scored according to race and indigence.

What has been discovered is a greater number of indigent that non-indigent sex offenders passed through these counties in 1992, with the likelihood of having treatment addressed in their sentencing order, being independent of their indigent status. Most indigent sex offenders plead guilty with charges dropped for their convictions, and received prison as a sentence. Most indigent sex offenders convicted were scored at 8-I on the sentencing guidelines matrix, which means they received sentences of prison for the crime(s) of Sex Abuse I, Rape II, Using a Child in a Display of Sexual Conduct, or Compelling Prostitution, with criminal histories that include minor misdemeanors or no criminal history at all. Most sex offenders across all races were indigent.

Hart (1958) found that the difference between criminal law and other laws is that criminal law reveals the judgement of the community condemnation which 
accompanies and justifies its imposition.

According to Tunick (1992), punishment meted through sentencing is based upon the Utilitarian theory which says that the function of punishment is to deter future crime, or incapacitate the dangerous criminal. In doing, there is possible reform of the criminal, and that punishment will bring about future good and increase the chances for positive social existence from the individual. Rawls (1971), found that utilitarian theory looks at the consequences of an action or practice, such as punishment, insisting that it is justifiable only if the future benefit outweighs the future cost. Reiman (1990), believes that as a society we should use punishment in such a manner that encourages deterrence, and not that the punishment itself creates an additional burden on society by perpetuating the criminality in an individual.

In looking at retribution as a theory for punishment, Tunick (1992), found that it delivers justice, expresses society's moral anger, condemnation and vindication, and that punishment should only be guided by the principle that it serves justice. Retribution theory concerns itself with the declaration that the action for a wrong to society conforms to a principle of justice, and any action in the name of justice is vindicated. Retribution manifests itself as retaliation and condemnation and can manifest through society's condemnation of an offensive act.

As availability of prison and jail beds decrease, it is essential that professionals in the field of criminal justice discriminate between those offenders who must be incarcerated to protect the public and those offenders who can be supervised with reasonable safety in community settings. Sexual, physical and emotional abuse of 
children causes untold costs to society as evidenced by the frequent appearance of such abuse in the background of most persons convicted of crime, particularly violent crime, in America. Such abuse often creates future abusers, or silent partners of abusers, which contributes to a society characterized by the spread of violence. One tool available in the attempt to supervise with reasonable safety is treatment for the illness of sexually offensive behavior. Though this tool's effectiveness is measured in various ways, as there are always examples of no effect at all, for the majority of those convicted of sexual offenses, it is a worthwhile consideration in the fight against recidivism of sexual offenders. If treatment of disease is important in protecting the public, then the attempt at costly treatment for the illness of sexual offenses should be given more attention. According to Dr. Barry Maletsky, of the indigent sex offenders sent to him for treatment by Multnomah County for treatment in 1992, there were actually only $2-5 \%$ that were truly indigent. Dr. Maletsky claims that with a thorough inventory of the financial situation of each client sent to him, he was able to establish some sort of payment plan with the client. Dr. Maletsky also points out, that the county never allows enough money to cover all the clients sent to him for treatment. Depending upon the program for treatment, some can take up to 18-24 months to complete. Dr. Maletsky combines differing types of behavior modification therapy tailored to the need of the client, such as, relapse therapy, cognitive skills, and socialization skills, to name a few. It is very important to remember that sex offenders need to receive the correct treatment procedures for their type of condition through thorough assessment. 
The current "get tough" philosophy is undermining the fight on crime by making sweeping sanctions that catch all offenders up in sanctions originally created for the most predatory. It is well known that Oregon has the highest rate nationally of indigent offenders passing through it's criminal justice system. Either the system is too lenient when appointing counsel for fear of violation of due process, doing so with out a thorough financial background check of the offender, or there are many offenders who simply cannot afford the high cost of legal representation, particularly for crimes of a sexual nature.

It has been said, "if you can't do the time, don't do the crime!', this is all very well for those who do know the difference between non-offense and offensive sexually criminal behavior. But what about those who lack the very basic skills necessary to keep them from re-offending? Is prison the answer? Prison is the most severe punishment in the correctional ensemble and should be reserved for those who cannot be brought to realize the severity of their crime by any other means.

If society continues to ridicule all sex offenders attempting to re-integrate safely back into society, as they have learned in treatment, we will see an increase in recidivism because for some the only escape from a life of persecution will be a return to criminality.

\section{Limitations of this Study}

Applying theory to criminality is an abstract task. In retrospect, other theories such as Hirschi's social control, might have also been used to support this study. 
The study did not take into consideration previous convictions or crime seriousness, but rather, let the sentencing guidelines matrix score control for this. The data group could have been reduced to include only sex abuse and certain violent offenses instead of including the whole range of felony sex offenses. Missing from this study was information on whether or not the offender had tried treatment before, was in treatment currently, or had been through treatment and this charge was due to recidivism, what the supervision status was at the time of the instant offense, and other information on the felony sentencing report, now known to the researcher, that could have contributed to the sentence decision. This information was not coded from the felony sentencing report by the researcher. Because treatment can only be recommended if the sentence is prison, the information available regarding incarceration treatment was not forth coming when inquired about. The reason given was confidentiality. What was received from Salem was the outline for probationary treatment provided by the Oregon State Hospital.

This is a "snapshot" of convictions in 1992; it does not have the benefit of examination of the presentence investigation report to find other influences as to the sentence type.

The original data base provided from the OCJC had 4 cases from this sample that received sentences of probation and jail. For purposes of simplicity, these four cases were combined into the prison variable on the rationale that there was some incarceration included in the sentence. 


\section{Strengths of this Study}

The findings of this report seem to hint at the possibility that sentencing guidelines is not meeting it's objective of reducing sentencing disparity. Also of interest is the large amount of indigent sex offenders that moved through the courts of these counties in 1992. The bulk of the offenders in this sample had sentencing guideline matrix scores that reflected crimes with no criminal history or minor misdemeanors. This could be, in part, due to the belief that by the time the sexual offender comes to the attention of the criminal justice system, many offenses have taken place, and these acts have either gone unreported or undetected. Or could the system be unduly harsh on these offenders? 


\section{DEFINITIONS AND TERMS}

Criminal HistoryCategory

A

B

C

D

E

F

G

$\mathrm{H}$

I

\author{
Descriptive Criminal History
}

The offender's criminal history includes three or more person felonies in any combination of adult convictions or juvenile adjudications.

The offender's criminal history includes two person felonies in any combination of adult convictions or juvenile adjudications.

The offender's criminal history includes one adult conviction or juvenile adjudication for a person felony; and one or more adult conviction or juvenile adjudication for a non-person felony.

The offender's criminal history includes on adult conviction or juvenile adjudication for a person felony; but no adult conviction or juvenile adjudication for a non-person felony.

The offender's criminal history includes four or more adult convictions for non-person felonies but no adult conviction or juvenile adjudication for a person felony.

The offender's criminal history includes two or three adult convictions for non-person felonies but no adult conviction or juvenile adjudication for a person felony.

The offender's criminal history includes four or more adult convictions for Class A misdemeanors; one adult conviction for a non-person felony; or three or more juvenile adjudications for nonperson felonies, but no adult conviction or juvenile adjudication for a person felony.

The offender's criminal history includes no adult felony conviction or juvenile adjudication for a person felony; no more than two juvenile adjudications for non-person felonies; and no more than three adult convictions for Class A misdemeanors.

The offender's criminal history does not include any juvenile adjudication for a felony or any adult conviction for a felony or Class A misdemeanor.

This criminal history definition is extracted from Mosbaek, 1993. 
Determinant sentencing - sentencing that equates to a known punishment

Deviant behavior-behavior deemed by society as apart from the norm

Felony sex offenders-having been convicted of one or more felony sex offenses

Felony sexual offense-as indicated on the sentencing guidelines matrix. This sample was convicted of one of the following as the most serious offense:

Rape I, II, III

Sodomy I, II, III

Sexual Abuse I

Sexual penetration I, II

Using a child in the display of sexual conduct

Promoting prostitution

Dealing child pornography
ORS $163.375,365,355$

ORS $163.405,395,385$

ORS 163.425

ORS 163.411, 408

ORS 163.370

ORS 167.012

ORS 163.673

Habilitation/rehabilitation-The learning and re-learning of socially acceptable methods of conduct

Indigent-the financial inability to afford counsel and subsequent costs incurred by the criminal justice system for crimes committed

Indigent defense-attorney appointed due to a claim of indigence by the accused

Privately retained counsel-attorney hired by the accused

Recidivate/recidivism-the condition of re-occurring criminal behavior

Sentence disposition-the sentence for the immediate crime being either probation of prison

Sentencing guidelines/matrix-guidelines developed for the purpose of equality in sentencing; the matrix is the instrument for determining the sentence

Sex offender treatment-Treatment designed to modify deviant behavior

Socio-economic status - the economic and class placement of an individual in society 


\section{REFERENCES}

Ashford, Kathyrn and Craig Mosbaek, (1992). Second Year Report on

Implementation of Sentencing Guidelines, Oregon Criminal Justice Council, pp.15-20

Betts v. Brady 316 US, 455, (1942)

Blumberg, A.S., (1967). "The Practice of Law as a Confidence Game: Organizational Co-adaptation of a Profession," Law and Society Review, New York, NY, New Viewpoints, vol.1, pp.15-39

Burke, R.J., Senior Judge, State of Oregon (personal communication, January 14, 1995)

Casper, Jonathan D., (1978). "Did You Have a Lawyer When You Went to Court? No I Had a Public Defender", Criminal Justice: Allies and Adversaries, John R. Snortum and Ilana Hader, eds., Palisades Publishing, Pacific Palisades, CA, pgs. 134-144

Chiricos, Theodore G., Phillip D. Jackson, and Gordon P. Waldo, (1972).

"Inequality in the Imposition of a Criminal Label," Social Problems, vol. 19, pp. 553-572

Colson, Charles W., "Alternative Sentencing: A New Direction for Criminal Justice," USA Today Magazine, May 1991, vol. 119. no. 2552, pp.64-66

Coser, Lewis, (1956). The Functions of Social Conflict New York, NY, Macmillian

Cressey, Donald, (1961). White Collar Crime, New York, Holt, Reinhart and Winston

Data base for Felony Sentencing Guidelines and The Oregon Justice Information Network supplied by The Oregon Criminal Justice Council, June 1992

Hart, Jr., Henry M., (1958). The Aims of Criminal Law, Law and Contemporary Problems, vol. 23, p. 404

Gideon v. Wainwright, 372 US, 335 (1963)

Gigeroff, Alex D. (1980). "Sex Offenders and the Sentencing Process," New Directions in Sentencing, B.A. Grosman, ed. Toronto, Buttersworth \& Co., pp. 235241 
Goffman, Irving, (1963). Stigma: Notes on Management of Spoiled Identities, New Jersey, Prentice-Hall

Irwin, John, (1985), The Jail: Managing the Underclass in American Society, University of California Press, Berkeley, pg. 5

MacLeod, Alistair W., (1965). Recidivism: A Deficiency Disease, Philadelphia, PA, University of Pennsylvania Press

Maletsky, Barry, (1991). Treating the Sexual Offender, Newbury Park, CA, Sage Publications

Maletsky, Barry, (personal communication, March 14, 1995)

Manhattan Bail Project (1967). "The Courts," Task Force Report, President's

Commission, Washington DC, US Government Printing Office, P. 319

Martin, Teri K. and John Hutzler, (1993). Adult Sex Offenders in Oregon: Trends and Characteristics, a project commissioned by the Oregon State Department of Corrections, Salem, OR

Matza, David, (1969). Becoming Deviant, New Jersey, Prentice-Hall

Merton, Robert K., (1949). Social Theory and Social Structure, Glencoe, IL, The Free Press

Moore, Michael, (1965). The Right to Counsel for Indigents in Oregon, Oregon Law Review, Eugene, OR, University of Oregon, pp.255-300

Mosbaek, Craig (1993). Third Year Report on Implementation of Sentencing Guidelines, Oregon Criminal Justice Council, pp.1-39

Myer, Martha A., (1987). "Income Inequality and Discrimination in Sentencing," Social Forces, vol. 65:3, pp.746-766

Nadar, Laura, (1990). "The Origins of Order and the Dynamics of Justice," New Directions in the Study of Justice, Law and Social Control, New York, NY, Plenum Press, pp.32-37

Petersilia, Joan and Susan Turner, (1986). "Prison versus Probation in California: Implications for Crime and Offender Recidivism," National Institute of Justice, United States Department of Justice, Rand Publications Series 
Petersilia, Joan and Susan Turner, (1987). "Guidelines Based Justice: The Implications for Racial Minorities," Don Gottfredson and Michael Tonry, eds., Prediction and Classification in Criminal Justice Decision Making, Chicago, University of Chicago Press

Piven, Frances and Richard Cloward, (1971). Regulating the Poor: The Functions of Public Welfare, New York, Random House

Quinney, Richard, (1977). Class State and Crime: On the Theory and Practice of Criminal Justice, New York, NY, McKay

Quinney, Richard, (1980). Class, State and Crime, Second Edition, New York, Longman

Rawls, John, (1971). Theory of Justice, The Belknap Press of Harvard University Press

Reiman, Jeffery, (1990). Justice and Modern Moral Philosophy, New Haven, Yale University Press

Sellin, Thorston (1958). Culture, Conflict and Crime, New York, Social Science Research Council

Senna, Joseph, J., and Larry J. Seigal,(1984). Introduction to Criminal Justice, 3rd ed., West Publishing, St. Paul, MN, pg. 378

Sudnow, David, (1965). "Normal Crimes: Sociological Features of the Penal Codes in the Public Defender's Office," Social Problems, pp.255-277

Sutherland, Edwin H. (1949). White Collar Crime, New York, Dryden

Sutherland, Edwin H. (1947). Principles of Criminology, Fourth Edition, Philadelphia, PA, J.B. Lippincott

Sykes, Gresham (1978). Criminology, R.K. Merton, ed., New York, Harcourt, Brace, Jovanovich

Tunick, Mark, (1992). Punishment: Theory and Practice, Berkeley, CA, University of California Press

Turk, Austin, (1966). "Conflict and Criminality," American Sociological Review, vol.31, pp.338-352 
Turk, Austin, (1976). "Law as a Weapon in Social Conflict," Social Problems, New York, NY, Society of Social Problems, vol.23, pp.277-291

Vold, George, (1958). Theoretical Criminality, New York, NY, Oxford University Press

Woodroofe, Kathleen (1962). From Charity to Social Work: In England and the United States, London, Routledge and Kegan Paul

Wright, Kevin N., (1991). "The Violent and Victimized in the Male Prison," Journal of Offender Rehabilitation, vol.16, Hayworth Press, pp.1-25 


\section{ENDNOTES}

1. Oregon Constitution, art. 1 , sect. 11

2. Corrections Compendium, U.S. Bureau of Prisons, 1991

3. The variable "treat" was in the original dataset from the OCJC, but did not represent the intended definition for the hypothesis testing, so an additional "treet" variable was created. 
APPENDICES

APPENDIX A

Sentencing Guidelines Matrix 


\section{SENTENCING GUIDELINES GRID}

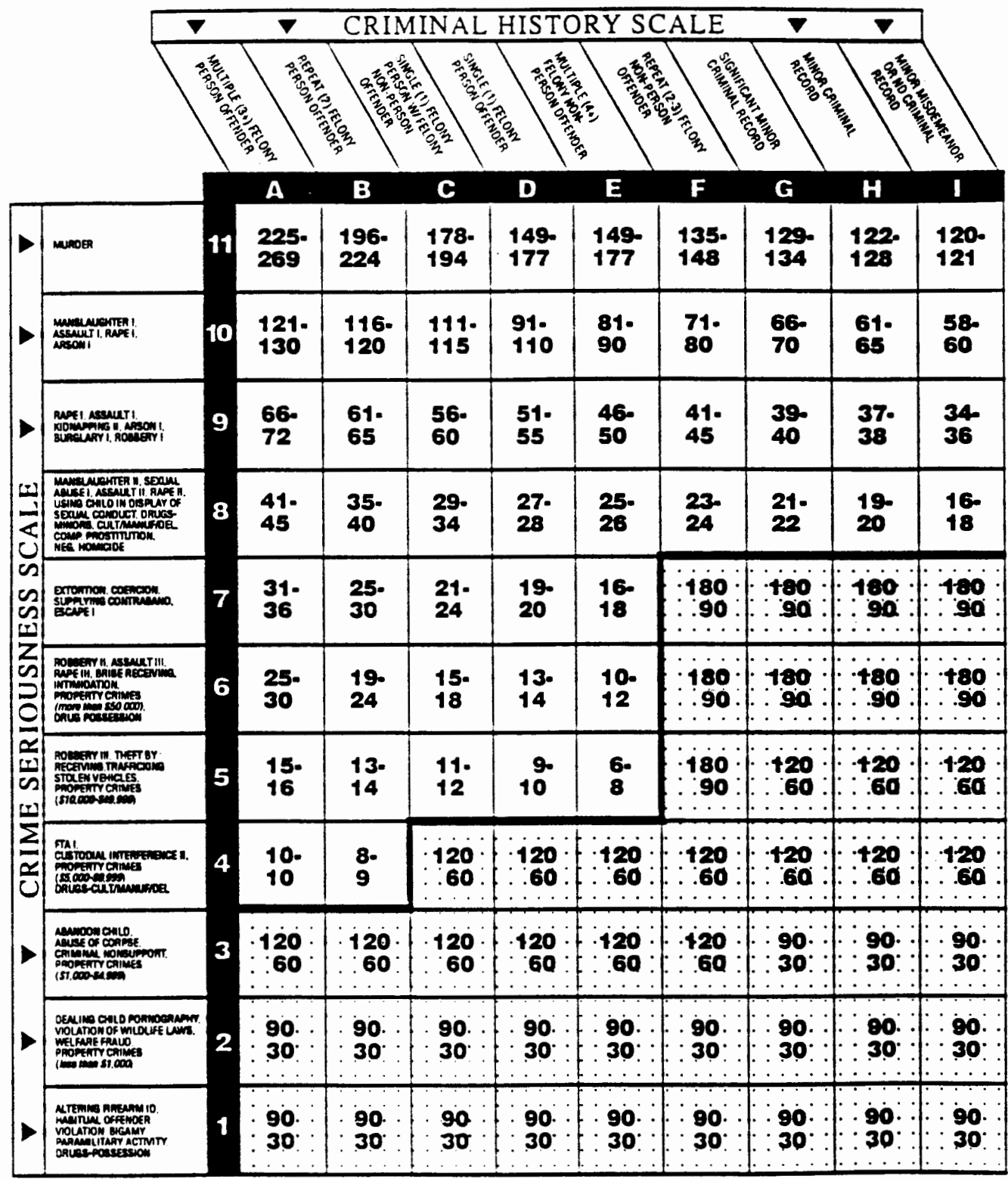

- In white blocks. numbers are presumotive onson sentences expressed as a range of months.

- In gray olocks. upder number is the maximum number of custoov units which may be imposed; lower number is the maximum numoer of latl days which may be imposed. 
APPENDIX B

Felony Sentencing Report 


\section{FELONY GUIDELINES SENTENCING REPORT}

- PLEASE PRESS FRMLY

PART A

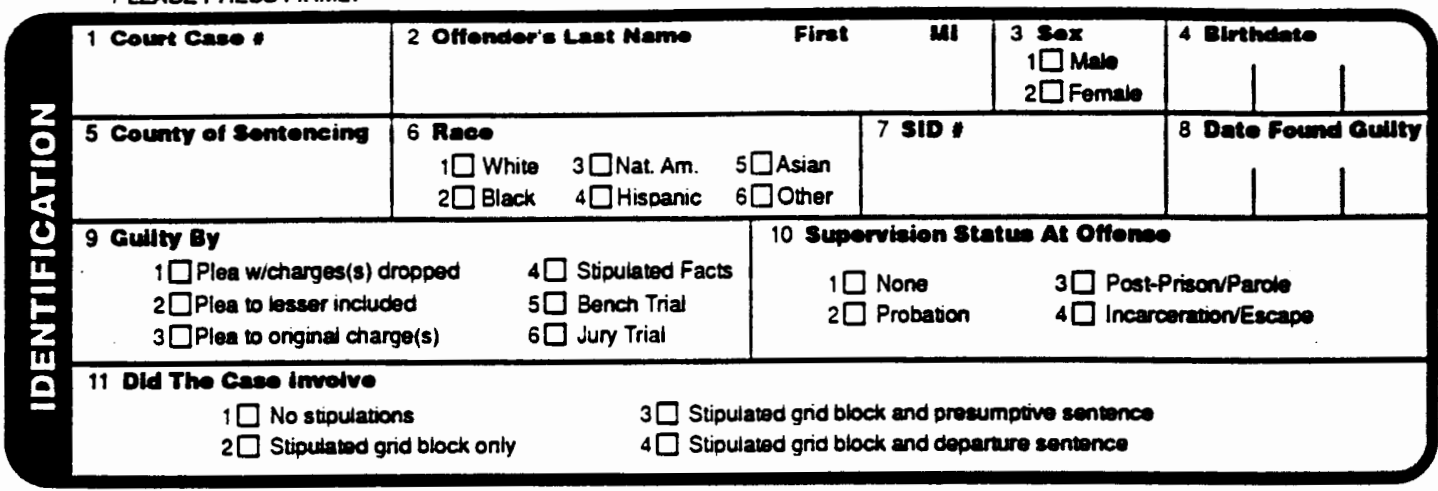

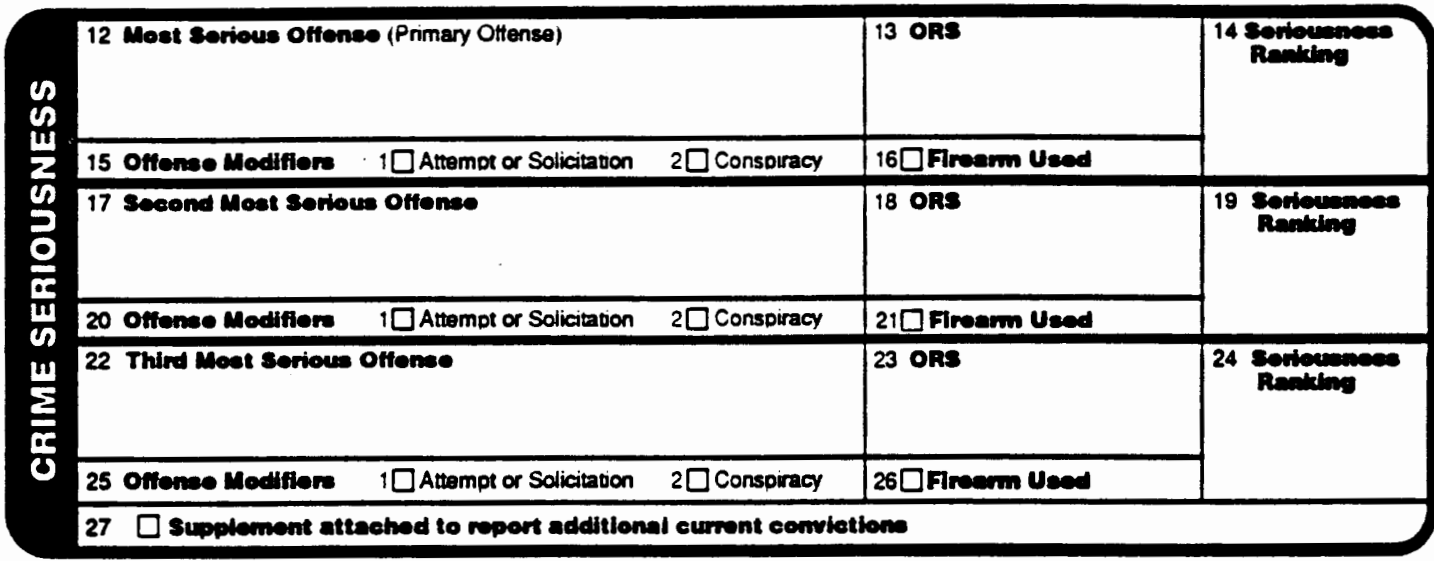

\begin{tabular}{|c|c|c|c|c|c|c|c|c|c|}
\hline $\begin{array}{l}\text { CRIMINAL HISTORY } \\
\text { CLASSIFICATION } \\
\text { (CIRCLE) }\end{array}$ & $\mathbf{A}$ & B & C & D & $\mathbf{E}$ & $F$ & G & & H \\
\hline
\end{tabular}

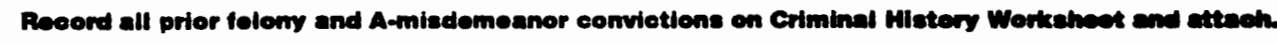

29 The preaumptive guideline sentence for the primary offenes bs
$1 \square$ A prison term of to months and
$2 \square$ A probationary senience
a post-prison supervision term of
months.
of monthe.

30 Additional current convictons: PRESUMPTIVE RANGE

Base Ranot

Second most senous io months

10 monthe

Third most senous 10 months to monthe 
PART B

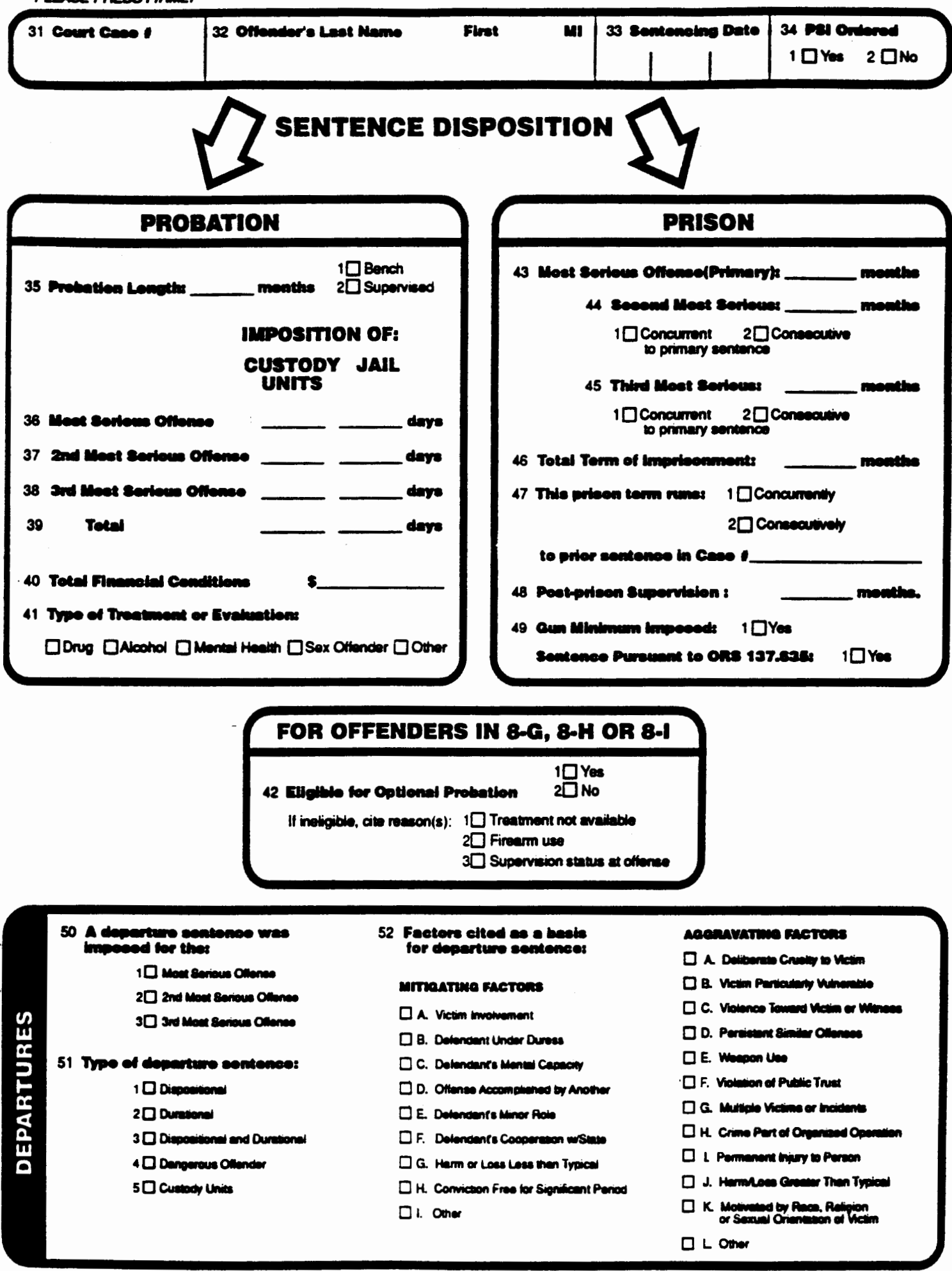

